wer in the city raises seedlings for a particular farmer, and then perhaps visits the farm and helps to plant the trees. Another facet of our rural activity is the regular planting and maintenance of an arboretum on sand-plain land in the 'wheatbelt' country north-east of Perth.

\section{Use of Exhibitions}

At the principal agricultural show each year in Perth, Men of The Trees has a high profile, with an exhibition illustrating what we do and how easy it is to rear and plant trees. At country shows and field-days, too, we 'show the flag' with a portable stall, from which we give out literature and seedlings.
Men of The Trees in Western Australia sees its role mainly as a catalyst, encouraging other people to plant trees, in the firm belief that eventually we will manage to convince people to care for this planet. After all, there is nowhere else to go!

CHRISTOPHER B. FYFE, Hon. Treasurer

The Men of The Trees (Inc.) Western Australian Branch 13 Wavell Road

Dalkeith

Western Australia 6009

Australia.

\title{
The Oleg Polunin Memorial Fund
}

\section{Background}

Oleg Polunin (1914-85) taught at Charterhouse for more than thirty years, inspiring many young biologists to undertake botanical and other scientific field-work. His own travels in Nepal and the Himalayas, as well as practically throughout Europe and in the Near and Far East, led to his great series of widely-reputed botanical field-guides. He recognized field-work as the key to his achievements, and was keen that Carthusians, after the completion of their schooling, should be able to continue with botanical studies in the field. The Fund has been established by his wife, family, and friends, both in his memory and to note the support given to him by the Governing Body of Charterhouse in his work.

\section{Aims}

The purpose of the Fund is to help those wishing to carry out work in the field of a botanical or general biological nature, either individually or as members of an organized expedition. Priority is given to those with Charterhouse connections, though others are also considered.

\section{The Fund and Conservation}

The Fund has been in operation since 1987 and there have been 11 beneficiaries to date, most of whom undertook field-work with a direct bearing on aspects of conservation.

In 1987, John Whitehead (Merrist Wood Agricultural College) went to Chile to collect natural-source conifer seed to secure genetic diversity to counteract the tendency to clone in commercial and private collections, to appraise the conservation status of these conifers in the wild, and to promote their cultivation to further their conservation.

In the following year 1988, Mark Nesbitt (the first Old Carthusian to receive a grant), of the British Institute of Archaeology at Ankara, studied archaic crop-plants particularly the Emmer and Einkorn varieties of wheat that were still in cultivation in remote areas of Anatolia, while in the same year, William Duckworth, of Cambridge University, received a share of the available grant to take part in an expedition to the Marojejy Reserve in Madagascar, recognized by IUCN and WWF as a particularly important area. This study sought to examine the distribution and abundance of mammals and birds in the reserve, and also Papilionid butterflies. In its course the first sighting in 58 years of the Madagascar Serpent Eagle (Eutriorchis astur), thought by many to have been extinct, was made and subsequently confirmed. In addition the threat was assessed to this northeastern part of the ever-shrinking Madagascan rain-forest, posed by agriculture and other human interference.

Other expeditions sponsored by the Oleg Polunin Memorial Fund have included a study of altitudinal zonation on Sibuyan Island, south-east of Manila, by a group from Sheffield University (led by Leonard J. Thomas), with a view to advising the Philippines Government over its use of this montane rain-forest as a potentially renewable resource. A Cambridge University undergraduate expedition (including two Old Carthusians, Scott Akker and Rosalind Highstead) was part-funded to study 'islands' of upland tropical forest surrounded by dry lowland savanna in Tanzania, as well as areas of high conservation priority owing to their small size and possession of recently evolved, and often unique, collections of species. This expedition aimed, in consultation with local scientists, to provide useful conservation data for the Government of Tanzania regarding damage through logging and other clearance operations.

Less exotic projects (but no less valuable for that) supported by the Fund have included research by Paul Whitehead into the Oil Beetle, Meloe rugosus (Red Data Book-listed and first discovered, by Whitehead, in Britain in 1984), the taxonomy of the genus Cotoneaster, by Jeanette Fryer, the taxonomy of the Loganiaceae (to form part of the Flora of Thailand project) by Olwyn Griffin, of Trinity College, Dublin, the distribution of certain brown seaweeds on the coast of north-east Britain, by Gavin Hardy, and a survey of Nepalese Alpine plants, including sketches and water-colour studies by Kathryn Jenkins (Old Carthusian) of Nottingham University.

\section{Future Funding and Applications}

The basic aims of the Fund remain the same, but it does seem that most projects based on field-work at the very least have environmental implications, and that many have direct bearing on some of the most important conservation issues facing us today. Thus the Fund can be seen as one not only to encourage field-work as an essential means of study in young scientists, but also as a way to further the cause of conservation. 
Applicants should write to the Headmaster, Charterhouse, Godalming, Surrey GU7 2DJ, England, UK, with a clear statement of their proposed field-work and the amount of grant requested. The sum normally available each year is up to $f 1,000$, and this total may be shared between several applicants.

\section{Donations}

Donations to the Fund will be warmly welcomed in the interests of increasing its usefulness and capability of helping qualified young scientists to do valuable field- work. They should be sent to The Clerk to the Governing Body, Charterhouse, Godalming, Surrey GU7 2DJ, England, UK, in the form of cheques made payable to 'The Bursar, Charterhouse' and endorsed 'For the Oleg Polunin Memorial Fund'.

\section{Marine Debris and Fishing off Irian Jaya}

Interviews with 'traditional' fishermen in Jayapura, Irian Jaya, Indonesia, have revealed that debris present in the sea has a negative impact on their fishing. In a particular case cited, the debris originates mostly from a municipal dump on a coastal cliff.

These traditional fishermen mainly use gill-nets and hook-and-line means to provide for their families. Sixteen persons were questioned about the impacts of waste on their fishing. All of them noticed waste in their usual fishing locations - consisting mainly of plastic bags, plastic bottles, and tin cans. They all agreed that the amount of waste is increasing with time. The impacts, as related by the fishermen, can be described as either directly or indirectly interfering with fishing.

The direct interference with fishing is illustrated by the hooking of plastic bags while trolling, or by a variety of objects entering the gill-nets when these are anchored for a few hours. The offending objects are most often plastic bags and glass or plastic bottles. These direct impacts include the cases where the net is torn or the hook is lost because of debris. This produces a lower fishing-yield (fewer fish are caught) and hence a lower income.

The indirect interference with fishing can be illustrated by examples varying from propeller entanglements, injuries sustained while walking barefoot on sand bars or while digging for shellfish, needs to change fishing locations or fishing gear (often against their best economic interest) because of the presence of wreckage or waste, and may include cleaning and/or repairing of nets. These indirect interferences cause a loss of income by increasing expenditures (e.g. for gear or engine repairs) or by increasing the amount of time spent on fishing-related activities (such as changing locations, cleaning or repairing nets and boat engines).

For fishermen living at the subsistence level, a slight decrease in income or fishing yield can have a major impact on their lives. In this case it may encourage them to adopt increasingly popular but destructive (and easier to use) fishing methods such as fishing with explosives or with cyanide - hence promoting further degradation of the coastal environment. The repercussions of this can be serious in South-east Asia, for instance, where an estimated 25 million people are directly dependant upon traditional marine fisheries for their livelihood (Smith, 1979).

\section{REFERENCE}

SMITH, IAN R. (1979). A research framcwork for traditional fisheries. Studies and Reviews, ICLARM Studies and Reviews No. 2, International Centre for Living Aquatic Resources Management, Philippines: [not available for checking].

ANNE D. NASH c/o WWF Irian Jaya

P.O.Box 525

Jayapura 99001

Irian Jaya

Indonesia.

\section{Contaminants in the Environment}

The University of Siena, Italy, is organizing a 2-weekslong 'Summer School for a Multidisciplinary Assessment of Environmental Risks for Human Health, lasting from 7 to 19 October 1991.

Topics will include:

- Distribution, levels, and fate;

- Comparative aspects of metabolism and toxicity;

- Detoxication strategies;

- Damage to biological structures; and

- Pesticides and risks for human health.

Food, lodging, and travel expenses will be provided for 15 Italian students; food, lodging, and part of travel expenses, will be provided for 15 foreign students.

Normally, a degree in Medicine or Biology is required, although possessors of degrees in related fields will also be considered. The official language will be English.
For due consideration, forward as quickly as possible your application, curriculum vitae, list of publications, letter(s) of recommendation, and a brief abstract regarding one of the above School topics (or your personal research) for possible short presentation during the School, to:

\section{ARISTEo ReNZoni, Professor Dipartimento di Biologia Ambientale Universita di Siena Via delle Cerchia 3 53100 Siena Italy.}

Telephone 0577-298831

Fax 0577-298860 Telex 572459 UNIVSI I. 